\title{
Management commitment and corporate sustainability integration into small and medium-scale enterprises: $A$ mediation effect of strategic decision-making
}

\section{Godfrey Adda *(D), Ghulam Ahmed Bin Donkor **iD,}

\section{John Bosco Azigwe * $\mathbb{D}$, Nii Afotey Odai ***iD}

* Bolgatanga Technical University,

Post Office Box 767, Sumburungu, Bolgatanga, Ghana

godfreyadda@bolgatu.edu.gh; john.azigwe@bolgatu.edu.gh

School of Business and Management Studies

** Ghana Communications Technology University;

Tawheed Group of Companies, Ahmadiyya Health Service,

Nsawam Rd, Accra, Ghana,

Department of Business Administration

gadonkormission11@gmail.com

*** SANA Research and Consultancy Ghana Limited,

Ghana

afotey777@gmail.com

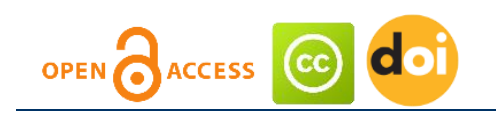

Article history:

Received: August 19, 2021

1st Revision: October 11,

2021

Accepted: November 22,

2021

\section{JEL classification: \\ Q50 \\ Q56 \\ L53}

DOI:

10.14254/jems.2021.6-2.1

\begin{abstract}
Corporate sustainability practices are vital to business survival. Hence, the need for targeted sustainable actions and corporate strategies capable of stimulating competitive advantage in terms of profitability and long-term existence of business entities. To this end, the study examines the influence of management commitment as an organisational factor on corporate sustainability integration in Ghana using corporate strategic decision-making as a mediating variable. Primary data was collected from SME owners and managers in Ghana; and the Warp partial least squares (PLS) estimation technique of the Structural Equation Model (SEM) was adopted for the analysis. The study makes a significant contribution to theory and knowledge in the context of SMEs within the corporate sustainability discourse. The study is situated on the empirical literature on the relevant concepts. This is followed by the methodology, analysis, discussions, findings, conclusions, contribution to knowledge, managerial implications, recommendations and limitations, followed by direction for future studies.
\end{abstract}


Keywords: corporate sustainability integration, management commitment, strategic decisionmaking, small and medium-scale enterprises, structural equation model.

\section{Introduction}

The 2020 World Economic Forum in Switzerland tasked business leaders to consider stakeholder demands for responsible corporate action, prioritize purpose over profit and identify unexpected spheres of their business activities (World Economic Forum, 2020). The forum also encouraged business leaders to fashion out cohesive global, regional and national strategies that are capable of changing corporate agenda towards sustainability. Similarly, the $73^{\text {rd }}$ United Nations General Assembly (UNGA) prevailed upon national leaders to ensure shared responsibilities for peaceful, equitable, and sustainable societies in tune with the Sustainable Development Goals (SDGs) (UNGA, 2020).

Corporate sustainability is about the creation of a shared value for all stakeholders simultaneously from short to long term. It focuses on the triple bottom line (TBL) - making a profit without neglecting the concerns of the people and planet, all of which are achievable through appropriate strategic decision-making (Ashrafi et al., 2019). The sustainability of businesses is vital because the success of corporate activities does not only rely on the availability of resources but also on how well enterprises successfully integrate sustainability into their operations (Sroka \& Szántó, 2018). Therefore, it is obligatory for businesses to see to the long-term societal and environmental concerns in addition to profit-making (Barney et al., 2020; Barry, 1999). The pursuance of corporate sustainability agenda has both tactical and economic implications for business enterprises because it has the potential of fixing the adverse impact of business operational activities on the environment and society in general (Salzmann, Ionescu-Somers \& Steger, 2005).

In Ghana, Small to Medium-Sized Enterprises (SMEs) contributes approximately $70 \%$ to the gross domestic product (GDP) (Peprah Mensah \& Akosah, 2016). As a result, SMEs are crucial and fundamental to the development and growth of the national economy (Asare, 2014). However, the survival rate of SMEs in Ghana is only 60\% beyond five years of operations (Peprah et al., 2016; Yeboah, 2015). Additionally, SMEs have often been described as laggards when it comes to commitment to sustainability (Revell et al., 2010). Not only that but also, there is a paucity of contextually relevant research to guide the players in the area of study since it is still evolving. Furthermore, although few studies have taken place in developed nations, little of this strand of studies has been situated in the context of developing nations, especially in sub-Saharan Africa.

Given that corporate sustainability practices are vital to businesses, targeted corporate sustainability actions and strategies could stimulate competitive advantage in terms of profitability and long-term survival. If SMEs fail to integrate sustainability into their strategic decision-making processes, the activities of these entities could engender negative consequences for economic fortunes as well as the environment and the society at large (Searcy, 2016). Nevertheless, SMEs often implement sustainability initiatives without integrating them into their strategic decision-making processes (Vandaele \& Decouttere, 2013).

To this end, the study examines the influence of management commitment as an organizational factor for corporate sustainability integration into SMEs in Ghana using corporate strategic decision-making as a mediating factor. The study makes a significant contribution to theory and knowledge in the context of SMEs within the corporate sustainability discourse. The study situated on an empirical literature review on the relevant concepts. The methodology, analysis, discussions, findings, conclusions, contribution to knowledge, managerial implications, recommendations and limitations, and direction for future studies then followed.

\section{Literature review and hypothesis development}

\subsection{Management commitment and corporate sustainability integration}

One of the pivotal factors in challenging the new global goals for sustainable development is the engagement of all businesses, including SMEs. Notwithstanding that SMEs are smaller and have less impact on the environment than larger businesses, they dominate the business arena in many countries (Sroka \& Szántó, 2018; Pless et al., 2012). The SME category of businesses is therefore central to sustainable development. 
SMEs' sustainability strategies are generally informal, while large firms' strategies have a higher degree of integration within the corporate strategy (Russo \& Tencati, 2009). Additionally, strategic corporate sustainability interventions are not vigorously pursued in SMEs in most countries, especially developing nations such as Ghana, due to a lack of awareness on the part of business owners and managers about the potential benefits they stand to gain. There is also limited access to affordable financial resources, inadequate knowledge, and skills regarding implementation techniques, and interference by competing initiatives with the conscious sustainability intentions. Nevertheless, sustainability needs to be integrated into an SME's business strategy, adopting a longterm vision for strategic benefits. An integration that may require the appropriate networks, resources, talent, innovation, and flow of information.

A crucial factor in engaging SMEs in the sustainability debate and practice will be the role of the owner-manager, bearing in mind that most small businesses are owned and managed by the same individual. The reason being that corporate sustainability requires business leaders that are humane and desirous of creating synergetic relationships leading to mutual benefits for all stakeholders simultaneously (Pirson \& Lawrence, 2010). To achieve a high level of sustainability, the commitment of top-level management and staff towards the sustainability vision of the enterprise is imperative (Eccle, Loannous \& Serafeim, 2014). One way of demonstrating management commitment towards sustainability integration into corporate strategic decision-making is by making sustainability an essential part of the firm's vision and mission (Muff \& Dyllick 2015; Dunphy et al. 2006). Other studies (Roome, 1992; Abid, 2013; Lyneis \& Sterman, 2016; Carmeli et al., 2017) advocated management commitment to commercial and environmental excellence. Also, the UN Global Compact (2007) emphasized the need for the commitment of corporate leadership towards developing the capabilities of stakeholders, frameworks, materials, processes, environment, and the engagement of SMEs in life-long sustainability learning activities to facilitate corporate sustainability integration. Similarly, the extension of corporate sustainability knowledge through interaction with fellow managers and owners of SMEs is equally crucial for sustainability integration (UN Global Compact, 2007; Liechti, 2014; Lyneis \& Sterman, 2016). Additionally, management's commitment towards the exploration of practical joint or collaborative approaches to meeting sustainability challenges would significantly contribute to corporate sustainability integration (Lozano, 2015; Liechti, 2014; Lyneis \& Sterman, 2016). Again, commitment to facilitating and supporting dialogue and debate on sustainability issues would also further sustainability integration (UN Global Compact, 2007; Liechti, 2014; Lyneis \& Sterman, 2016). Not only that but also, the commitment of SME managers and owners to finding the needed financial resources is fundamental for sustainability integration implementation success (George et al., 2016; Golini et al., 2014). Thus, commitment to sustainability can be understood as an overarching view that sustainability is a crucial component in several of the firm's processes and procedures, such as overall management philosophy, strategic product decisions, competitiveness, and strategic planning (Pless et al., 2012).

Corporate sustainability integration demands strong and progressive leadership, opportunity seekers, integrators and crusaders, as against the traditional business mindset of creating value for only the owners or shareholders of businesses. It also calls for organizational leaders who demonstrate and inspire their employees for collaboration in all frontiers of their enterprise towards the sustainability strategy (Dyllick \&Muff, 2015). Top management, together with supervisors and the generality of staff, should exhibit positive sustainability behaviors to manifest their commitment to sustainability. They are also more likely to trust and have a positive perceptions about their organization if they think top management is committed to sustainability.

The critical elements to implementing sustainable business practices in SMEs' strategy and planning can take the following form (Hörisch, Freeman \& Schaltegger, 2014; Krechovská, 2012; Stark et al., 2017; Galpin \& Hebard, 2018; Smith \& Ronnegard, 2014): 1) a broad view of sustainability by understanding the key sustainability drivers and opportunities in the organization; 2) a clear definition of sustainability for all stakeholders, e.g., right goals and success measures; 3) engagement with all stakeholders about sustainability; 4) execution and alignment with national, international and industry-wide sustainable initiatives; 5) establishing responsibility and communication for ownership. Hence, the study hypothesizes that:

H1: Management commitment positively relates to corporate sustainability integration.

\subsection{Management commitment and strategic decision making}

Various studies (e.g., Bonn \& Fisher, 2011; Baumgartner \& Ebner, 2010; Jin \& Bai, 2011) highlighted a link between the attitudes of managers and the integration of corporate sustainability through strategic management processes. In the assertion of Maon et al. (2008), strategy design impacts the perceptions and attitudes of managers; and that the behavior of middle-level managers 
is a reflection of that of the senior-level managers. According to Harmon et al. (2009), internal structural deficits could negatively impact the chances for a fruitful business sustainability integration, even if there is a change in the attitude and behavior of managers.

Similarly, other studies (e.g., Pless et al., 2012; Euler \& Hahn, 2007; Svanstom, Lorenzo-Garcia \& Rowe, 2008; Sterling \& Thomas, 2006; Wiek, Withcombe \& Redman, 2011; Dassah, 2010) have linked the various leadership styles to business sustainability types. According to Khurana and Nohria (2008), managers ought to view themselves as trustees of the society, who are responsible for the prosperity of their businesses, and also serving the public interest. Also, comparing the leaders' values with the sustainability strategies in SMEs, Kaldschmidt (2011) established a correlation between business leaders that adopted proactive sustainability strategies and their values of exhilaration and directness to transformation.

A sustainability strategy is not only crucial for sustainable development but also a guiding tool for SMEs to succeed in meeting their social, environmental, and economic requirements, including competitive market conditions (Sroka \& Szántó, 2018). Further, due to the growing demands on corporations to measure up to sustainability reporting requirements and other accounting, and corporate governance standards, there is mounting pressure on SMEs to mainstream sustainability initiatives into their operations (Brammer, Hoejmosr \& Marchant, 2012). At the same time, some of the factors that affect the integration process for SMEs include: internal (company size, scope, and structure); external drivers (industry type, structure, and position within the industry); and the promoting and inhibiting factors, all of which interact and correlate in actual corporate practice. The initial cost of integrating sustainability into the core business strategy and reporting can be counterbalanced through cost savings, reduced risk, positive brand association, and the ability to meet consumer, investor, and supplier demand for environmentally conscientious products and services. Following the above, the study postulates that:

H2: Management commitment positively relates to strategic decision-making.

\subsection{Strategic decision-making and corporate sustainability integration}

Notwithstanding their significance, SMEs continue to trail behind when committing to sustainability (Revell et al., 2010). In the context of the evolution of the responsibility towards internal and external stakeholders, enterprises have to deal with the challenge of adapting strategic orientation and operative value creation for current and future stakeholders. To meet the requirements set forth by the triple bottom line - profit, people and planet (Dyllick \& Hockerts, 2002), and the sustainability strategies, SMEs have to adapt their corporate strategies.

A strategy refers to the deliberate or emergent choices (purpose, priorities, goals) that distinctively position a business brand or product for sustainable competitive advantage and value creation (Porter \& Kramer, 2011). The strategy should precede action (Mintzberg, 1990). Therefore, a firm's sustainability efforts should begin at the organization-wide strategic management level. Thus, a strategy describes the total sum of a firm's plans, goals, capabilities, resources, and actions leading to measurable results (Galpin, Whittington \& Bell, 2015). This seeming integrated view of the firm is in contrast to the traditional approach to strategic planning, which characterizes the systematic formulation of strategies geared toward achieving organizational goals (Mintzberg, 1987).

Corporate strategic decision-making refers to top-level management choices made at the corporate level by managers and, or owners for maximizing financial performance and as well, achieve other non-financial goals beneficial to the people and the planet in the short and long-terms (Hörisch, Freeman \& Schaltegger, 2014; Krechovská, 2012; Stark et al., 2017; Galpin \& Hebard, 2018; Smith \& Ronnegard, 2014). In developing a comprehensive corporate strategy, consideration is given to the requirements of internal and external stakeholders, specifically the various sustainability perspectives (Borges et al., 2018). According to Figge et al. (2002), these choices include: 1) adjusting the corporate strategy to include objectives regarding economic, ecological, and social performance; 2) defining a specific sustainability strategy as part of the corporate strategy and; 3) redefining the corporate strategy based on the premise of creating a holistic sustainability strategy.

Cici and D'Isanto (2017: 54) define the integration of sustainability as "redesigning and redefining strategy and operative processes to face the changes and meet the needs and expectations of the market and society alike, with the ultimate goal of increasing competitiveness and supporting durable profitability." Incorporating sustainability into the core strategy of an organization (enterprise, business unit or function) is used to describe the deliberate, or emergent choices (purpose, priorities, goals) that are made to distinctively position the enterprise, brand or product for sustainable competitive advantage and value creation (Galpin \& Hebard, 2018). 
Incorporating sustainability into the core strategy of organizations can take the following forms (Hörisch, Freeman \& Schaltegger, 2014; Krechovská, 2012; Stark et al., 2017; Galpin \& Hebard, 2018; Smith \& Ronnegard, 2014): 1) establish a clear sustainability objective as an achievable goal as a corporate agenda; 2) engage and collaborate with business partners in assessing the environmental and social impacts of operations; 3) engage customers regarding the need for sustainability in terms of environmentally friendly or fair-trade products; 4) communicate sustainability goals throughout the organization, where every individual, regardless of their role, needs to understand and embrace that sustainability vision; 5) develop conditions that support sustainability-oriented innovations.

The sustainability integration strategies often adopted by corporate entities are likewise classified as follows (Roome, 1992): 1) defensive sustainability integration strategy (limited integration) or "compliance strategy," 2) accommodative integration sustainability strategy (integration) or Roome's "compliance-plus strategy," 3) proactive integration sustainability strategy (full integration) also known as "commercial and environmental excellence" or "leading edge." It is essential to integrate sustainability into all organizational units and at all management levels to contribute to sustainable development. This integration should involve: a) top management support, and b) an open organizational culture regarding sustainable development so as to integrate sustainability at the operational, strategic, and normative management levels.

Corporate sustainability integration entails a process of developing learning structures and fundamental change processes with the ultimate aim of questioning and rethinking a firm's relationships with the planet and people, in addition to the profit motives for incorporating them into corporate strategies for implementation and reporting. This begins with advancing a business case for the integration, assessing the drivers of the integration, coupled with the factors that could either promote or inhibit the integration process. Among the core issues to consider are, 1) costs and cost reduction (Christmann, 2000), 2) sales and profit margins (Porter \& Kramer, 2006, 2011), 3) risk and risk reduction (Schaltegger \& Wagner, 2006; Loew et al., 2011), 4) reputation and brand value (Marrewijk 2003), 5) attractiveness as an employer (Ehnert, 2009; Revell et al., 2010), and 6) innovative capabilities (Cohen \& Winn, 2007; Schaltegger \& Wagner, 2011). It is, therefore, postulated that:

H3a: Strategic decision-making positively associates with corporate sustainability integration. $H 3_{\mathrm{b}}$ : Strategic decision-making mediates the relationship between management commitment and corporate sustainability integration.

\begin{tabular}{lc} 
Table 1: Summary of hypotheses & \multicolumn{1}{c}{ Hypothesis } \\
\hline P1: There is a positive relationship between MC and CSI & + \\
$H 2:$ There is a positive relationship between MC and SDM & + \\
$H 3$ a: SDM positively associates with CSI & + \\
$H 3$ b: SDM mediates the relationship between MC and CSI & + \\
\hline
\end{tabular}

\section{Methodology}

The drive of this study was to examine the influence of management commitment as an organizational factor on corporate sustainability integration in Ghana using corporate strategic decision-making as a mediating factor. The study adopts a quantitative approach in examining the relationships between the variables. The study adopted the Warp Partial Least Squares (PLS) estimation technique of the Structural Equation Model (SEM) for the analysis. The source of data for the study is primary data.

\section{Sampling}

The target population was SMEs $(\mathrm{N})=488$ registered with the National Board for Small Scale Industries (NBSSI) in the Greater Accra Region as of May 2020. Out of this total, a sample of SMEs (N) $=400$ was drawn for the study, representing $82 \%$. The stratified random sampling was used in an attempt to give an equal chance of inclusion (i.e., Creswell, 2015). The sample comprised of SME managers/owners because of their critical role in the firms, and their knowledge and access to vital information, all of which were relevant to the study. Also, the researchers wrote a formal letter to the Executive Director of NBSSI indicating the rationale of the study. After approval, the researchers, NBSSI, and participants signed a Memorandum of Understanding (MOU) to protect personal and confidential information that might emerge from the study. 


\section{Instrument}

A five-point Likert scale (1 - Strongly disagree, 2 - Disagree, 3 - Neutral, 4 - Agree, 5 - Strongly agree) type questionnaires was developed for data collection. A pre-test of the questionnaires was carried out with fifty (50) SME owners and managers to gauge their suitability (Sweeney, 2009). Based on feedback, the researchers revised the questionnaires in terms of wording, sequencing, and number of the questions. Also, the researchers reframed questionnaire items that were unclear or ambiguous. Further consultations were also made with the participants to ensure a high response rate. In the end, a total of 400 questionnaires were administered to managers and owners of SMEs. Out of that number, 390 of the completed questionnaires were received, representing a response rate of $98 \%$.

\subsection{Measurement of variables}

Table 2 below demonstrates how the variables, the research questions, and the items on the survey instrument relate. The information helps ascertain the connection between the data, variables, and questions or hypotheses (e.g., Creswell, 2015). It also shows how the survey items were measured.

\begin{tabular}{|c|c|c|}
\hline Variables & Research Questions & $\begin{array}{c}\text { Items on Survey } \\
\text { (Likert Scale } 1 \text { to 5) }\end{array}$ \\
\hline $\begin{array}{l}\text { Dependent variable: } \mathrm{CS} \\
\text { Integration }\end{array}$ & $\begin{array}{l}\text { How do the factors inhibiting corporate } \\
\text { sustainability integration relate to corporate } \\
\text { strategic decision-making of SME managers } \\
\text { and owners in Ghana? }\end{array}$ & CSI1, CSI2, CSI3, CSI4, CSI5. \\
\hline $\begin{array}{l}\text { Independent variable: } \\
\text { Management } \\
\text { Commitment }\end{array}$ & $\begin{array}{l}\text { How does management commitment relate } \\
\text { to corporate sustainability integration into } \\
\text { corporate strategic decision-making? }\end{array}$ & $\begin{array}{l}\text { MC1, MC2, MC3, MC4, MC5, MC6, } \\
\text { MC7, MC8, MC9, MC10, MC11, } \\
\text { MC12. }\end{array}$ \\
\hline $\begin{array}{l}\text { Mediating variable: } \\
\text { Strategic Decision } \\
\text { Making }\end{array}$ & $\begin{array}{l}\text { How does strategic decision-making relate } \\
\text { to corporate sustainability integration? }\end{array}$ & $\begin{array}{l}\text { SDM1, SDM2, SDM3, SDM4, } \\
\text { SDM5, SDM6, SDM7, SDM8. }\end{array}$ \\
\hline
\end{tabular}

\section{Analysis}

After sorting the completed questionnaires, the researchers deleted all the wrongly filled questionnaires including those with missing values. In the end, 390 valid questionnaires were entered using Microsoft Excel 2016. In subsequent steps, the data were exported to WarpPLS 7.0. for preliminary analysis and diagnostic tests. The preliminary analysis included missing value analysis (Little MCAR test) and outlier analysis using the Mahalanobis test. The unit of analysis was at the individual level comprising of SME owners and managers.

The dependent and independent variables were analysed descriptively. Guided by the research objectives, the directions and strengths of the relationships between the variables were measured, and analyzed. Additionally, the researchers analysed the sign, magnitude and significance of the path coefficients. Also, the inferential analysis conducted helped to establish whether the relationships between the variables were significant. The presented results of the analysis were in the form of tables and figures as below.

\begin{tabular}{|c|c|c|c|}
\hline $\begin{array}{l}\text { Latent } \\
\text { Variables }\end{array}$ & Composite Reliability & $\begin{array}{l}\text { Cronbach's } \\
\text { Alpha }\end{array}$ & $\begin{array}{c}\text { Dijkstra's PLSc } \\
\text { Reliability }\end{array}$ \\
\hline Corporate Sustainability Integration & 0.822 & 0.700 & 0.725 \\
\hline Management Commitment & 0.807 & 0.873 & 0.854 \\
\hline Strategic Decision Making & 0.821 & 0.748 & 0.729 \\
\hline
\end{tabular}

Source: Warp-PLS Output of the Study Data (2020)

Table 3 above presents the reliability analysis for the constructs. As can be observed from the table, the Cronbach's Alpha for all the latent variables exceeded the threshold value of 0.7 which is reliable and satisfactory (i.e., Cronbach, 1951). Table 3.0 also presents the composite reliability score and Dijkstra's PLS reliability score. The results revealed that both reliability measures also obtained reliability scores that were above 0.7 , which implies the scales used to measure the latent variables are reliable. 
Table 4: Convergent validity for constructs.

\section{Latent}

Variables

Average Variance Extracted (AVE)

Corporate Sustainability Integration

0.656

Management Commitment

0.776

Strategic Decision Making

0.674

Source: Warp-PLS Output of the Study Data (2020)

Table 4 above demonstrates the convergent validity for the constructs. Convergent and discriminant validity are that both sub-categories of construct validity. The convergent validity results presented in Table 4 revealed that the AVE values ranged from 0.656 to 0.776 and above 0.5 . Hence, the model achieved convergent validity.

\begin{tabular}{lccc}
\multicolumn{4}{l}{ Table 5: Correlations between latent variables (Fornell-Larcker Criterion) } \\
\hline Latent & CSI & MC & SDM \\
Variables & $\mathbf{0 . 8 7 5}$ & & \\
\hline CSI & 0.723 & $\mathbf{0 . 8 2 0}$ & $\mathbf{0 . 8 6 8}$ \\
MC & 0.647 & 0.754 &
\end{tabular}

Source: Warp-PLS Output of the Study Data (2020)

\section{Table 6: Heterotrait-Monotrait (HTMT) Ratio}

\begin{tabular}{lccc}
\hline Latent & CSI & MC & SDM \\
Variables & & & \\
\hline CSI & 0.645 & & \\
MC & 0.578 & 0.728 & \\
\hline
\end{tabular}

Source: Warp-PLS Output of the Study Data (2020)

It can be observed from Table 5 that the diagonal values for the correlations between the latent variables exceeded the correlations between the other constructs. For example, the diagonal value for CSI in column 1 (0.875) was more significant than 0.723 and 0.647 . In using the HTMT statistic to check for discriminant validity, Kock (2017) and Henseler, Ringle, and Sarstedt (2015) assert that the HTMT values should not exceed 0.90 in order to achieve discriminant validity. Results from Table 6 show that the HTMT values were below 0.9 .

Table 7: Collinearity Results using PLS-SEM

\begin{tabular}{|c|c|c|c|}
\hline $\begin{array}{l}\text { Latent } \\
\text { Variables }\end{array}$ & Item & Item VIF Value & Construct VIF Value \\
\hline \multirow[t]{5}{*}{ CSI } & CSI1 & 1.678 & 1.415 \\
\hline & CSI2 & 1.637 & \\
\hline & CS13 & 1.386 & \\
\hline & CS14 & 1.350 & \\
\hline & CSI5 & 1.416 & \\
\hline \multirow[t]{12}{*}{ MC } & MC1 & 1.385 & 1.730 \\
\hline & MC2 & 1.535 & \\
\hline & MC3 & 1.527 & \\
\hline & MC4 & 1.435 & \\
\hline & MC5 & 1.391 & \\
\hline & MC6 & 2.038 & \\
\hline & MC7 & 1.417 & \\
\hline & MC8 & 1.313 & \\
\hline & MC9 & 1.214 & \\
\hline & MC10 & 1.408 & \\
\hline & MC11 & 1.420 & \\
\hline & MC12 & 1.406 & \\
\hline \multirow[t]{8}{*}{ SDM } & SDM1 & 1.245 & 2.050 \\
\hline & SDM2 & 1.476 & \\
\hline & SDM3 & 1.213 & \\
\hline & SDM4 & 1.378 & \\
\hline & SDM5 & 1.237 & \\
\hline & SDM6 & 1.371 & \\
\hline & SDM7 & 1.252 & \\
\hline & SDM8 & 1.465 & \\
\hline
\end{tabular}

Source: Warp - PLS Output of the Study Data (2020) 
According to Field (2009), multicollinearity is when two or more independent variables in a regression model are highly correlated. The high correlation between the independent variables can be problematic for the model fit and interpretation of the regression results (Mansfield \& Helms, 1982). According to Field (2009), a construct or an item with a variance inflation factor (VIF) value greater than 5 implies that the item or construct has a multicollinearity problem. From Table 7, all the items and constructs obtained VIF scores that were less than 5. The results show that no two or more independent variables in the model are highly correlated. Hence, no multicollinearity problems.

\begin{tabular}{|c|c|c|c|}
\hline $\begin{array}{l}\text { Latent } \\
\text { Variables }\end{array}$ & CSI & MC & SDM \\
\hline CSI1 & 0.780 & & \\
\hline CSI2 & 0.821 & & \\
\hline CS13 & 0.732 & & \\
\hline CS14 & 0.682 & & \\
\hline CSI5 & 0.637 & & \\
\hline MC1 & & 0.757 & \\
\hline MC2 & & 0.632 & \\
\hline MC3 & & 0.684 & \\
\hline MC4 & & 0.626 & \\
\hline MC5 & & 0.715 & \\
\hline MC6 & & 0.655 & \\
\hline MC7 & & 0.767 & \\
\hline MC8 & & 0.648 & \\
\hline MC9 & & 0.661 & \\
\hline MC10 & & 0.628 & \\
\hline MC11 & & 0.661 & \\
\hline MC12 & & 0.626 & \\
\hline SDM1 & & & 0.722 \\
\hline SDM2 & & & 0.638 \\
\hline SDM3 & & & 0.613 \\
\hline SDM4 & & & 0.632 \\
\hline SDM5 & & & 0.621 \\
\hline SDM6 & & & 0.652 \\
\hline SDM7 & & & 0.670 \\
\hline SDM8 & & & 0.651 \\
\hline
\end{tabular}

Source: Warp-PLS Output of the Study Data (2020)

In PLS-SEM, the factor loadings define the total contribution of an item to its assigned latent variable or construct (Hair et al., 2016). According to Shevlin and Miles (1998), the value for factor loadings should be at least 0.5 to be deemed appreciable. Shevlin and Miles have, however asserted that a more stringent criterion are that it should exceed 0.7 or be closer to 0.7 . The results presented in Table 8.0 showed that all the items in the structural equation model obtained factor loadings that were all above 0.5 . The outcome implies that the items in our model obtained appreciable factor loadings scores. Hence, the total contribution of the items to their assigned latent variables or constructs is all within the acceptable thresholds.

\begin{tabular}{lccccc}
\multicolumn{2}{l}{ Table 9: Results for the path analysis } \\
\hline Hypothesis & $\begin{array}{c}\text { Hypothesized } \\
\text { Path }\end{array}$ & $\begin{array}{c}\text { Path } \\
\text { Coefficient }\end{array}$ & T Statistics & SE & P Values \\
\hline$H 1$ & MC -> CSI & 0.280 & 5.553 & 0.050 & 0.001 \\
$H 2$ & MC - SDM & 0.331 & 0.632 & 0.142 & 0.032 \\
$H 3$ & SDM -> CSI & 0.272 & 5.341 & 0.051 & 0.001 \\
\hline
\end{tabular}

Table 9 presents the results for the path analysis for the structural equation model. From the results, the path coefficient for the relationship between MC and CSI was 0.280 , with a significant value of $p<0.001$. The results imply that there is a significant and positive relationship between MC and CSI. There was also a significant and positive relationship between SDM and CSI (path coefficient $=0.272, p<0.001$ ). Similarly, there was a significant relationship between MC and SDM (path coefficient $=0.331, p=0.032$ ). 
Table 10: Results for indirect path analysis

\begin{tabular}{lcccc}
$\begin{array}{l}\text { Hypothesized } \\
\text { Path }\end{array}$ & Path Coefficient & T Statistics & SE & P Values \\
\hline MC $>$ CSI & 0.230 & 5.542 & 0.052 & $<0.001$ \\
\hline
\end{tabular}

Source: Warp-PLS Output of the Study Data (2020)

\section{Mediation analysis}

From Table 9 and Figure 1, the results of the structural model demonstrate that MC contributes significantly towards predicting $\operatorname{CSI}(\beta=0.280, p<0.001)$. Not only that, but also, the results reveal the extent to which SDM contributes towards $\operatorname{CSI}(\beta=0.272, p<0.001)$. Furthermore, the results indicate that MC contributes significantly towards $\operatorname{SDM}(\beta=0.331, p<0.032)$. As previously observed, the direct effect between MC and CSI are significant $(\beta=0.280, p<0.001)$ (See table 9.0). Similarly, the indirect effect between MC and CSI is significant $(\beta=0.230, p<0.001)$ (See table 10.0). Once the P values associated with the direct effect between MC and CSI are significant, and; the $P$ values associated with the indirect effect of the same variables are equally significant, it means that partial mediation has occurred between MC and CSI. Therefore, ${ }_{3} \mathrm{Hb}_{\mathrm{b}}$ is partially supported.

Figure 1: Structural model results

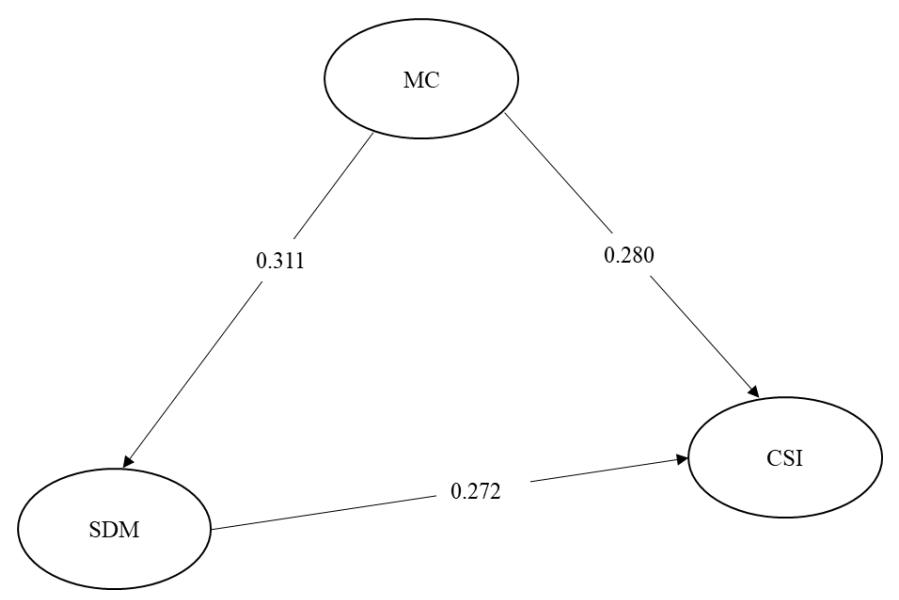

\section{Discussions}

The discussion of the results is situated on the objectives and outcomes of the hypothesized relationships in the study variables. The results suggest that there is a significant and positive relationship between management commitment and corporate sustainability integration. Abid (2013) and Lyneis and Sterman (2016) posited that management commitment to non-financial issues is crucial if the integration of sustainability into corporate strategic decision making and business practice is to succeed. Also, the results corroborate the view that securing top-level management commitment is crucial for smooth sustainability integration, as advocated by Eccle, Loannous, and Serafeim (2014). Furthermore, other studies (e.g., Pless et al., 2012; Euler \& Hahn, 2007; Svanstom, Lorenzo-Garcia \& Rowe, 2008; Sterling \& Thomas, 2006; Wiek, Withcombe \& Redman, 2011; Dassah, 2010) also underscored the need for management commitment towards corporate sustainability integration. In sum, the outcome of the hypothesis is in tandem with extant literature. As a result, business enterprises should endeavor to give due attention to the environmental and social impact of their activities to gain sustainable competitiveness and optimal economic outcomes (Farla et al., 2012; Kolk \& Van Tulder, 2010; Michelon et al., 2013).

There is also a significant and positive relationship between strategic decision-making and corporate sustainability integration. Equally, there is a significant relationship between management commitment and strategic decision-making. Specifically, there is a direct effect between management commitment and corporate sustainability integration which is significant. Similarly, there is an indirect effect between management commitment and corporate sustainability integration which is significant. Hence, there is a partial mediation between management commitment and corporate sustainability integration through strategic decision-making. Thus, strategic decision-making accounts for some, but not all, of the relationship between management commitment and corporate sustainability integration. One way of demonstrating management commitment towards sustainability integration into corporate strategic decision-making is by making sustainability an essential part of the firm's vision and mission (Muff \& Dyllick, 2015; Dunphy et al., 2006). Other 
studies (Roome, 1992; Abid, 2013; Lyneis \& Sterman, 2016; Carmeli et al., 2017) advocated management commitment to commercial, and environmental excellence. Also, there is the need for SMEs to develop the sustainability capabilities of their stakeholders, frameworks, materials, processes, environment, and the engagement of SMEs in life-long sustainability learning activities so to facilitate corporate sustainability integration. Likewise, the extension of corporate sustainability knowledge through interaction with fellow managers and owners of SMEs is equally crucial for sustainability integration (UN Global Compact, 2007; Liechti, 2014; Lyneis \& Sterman, 2016). Furthermore, management's commitment towards the exploration of practical joint or collaborative approaches to meeting sustainability challenges would significantly contribute to corporate sustainability integration (Lozano, 2015; Liechti, 2014; Lyneis \& Sterman, 2016). Again, commitment to facilitating and supporting dialogue and debate on sustainability issues would also further sustainability integration (UN Global Compact, 2007; Liechti, 2014; Lyneis \& Sterman, 2016). Not only that but also, the commitment of SME managers and owners to finding the needed financial resources is fundamental for sustainability integration implementation success (George et al., 2016; Golini et al., 2014).

\section{Conclusions}

The study examined the influence of management commitment as an organizational factor for corporate sustainability integration into SMEs in Ghana, focusing on the mediating role of corporate strategic decision-making. Thus, the consistent relationship between management's commitment and corporate sustainability integration of SMEs may be as a result of the mediating role of strategic decision-making. From the discussions above, there is a significant and positive relationship between management commitment and corporate sustainability integration. Also, there is a significant and positive relationship between strategic decision-making and corporate sustainability integration. Similarly, there is a significant relationship between management commitment and strategic decision-making. The results suggest that strategic decision-making partially mediates the nexus between management commitment and corporate sustainability integration. Therefore, strategic decision-making accounts for some, but not all, of the relationship between management commitment and corporate sustainability integration.

\section{Recommendations}

The study has important implications for management and corporate entities. The study stresses that owners and managers of SMEs should not embark on sustainability integration just by simply reacting to institutional or stakeholder demands without integrating such sustainability intentions into their strategic decision-making processes. Simply put, SMEs should demonstrate enormous commitment towards corporate sustainability integration into the strategic decisionmaking processes of their firms. They should strive to make corporate sustainability integration an essential part of the visions and missions of their enterprises. When corporate sustainability is embedded into what the enterprises stand for, it becomes a crucial part of everyday decision-making. Also, SMEs managers and owners should be committed to both commercial and environmental excellence of their firms and the development of stakeholder capabilities. Furthermore, owners and managers of SMEs should demonstrate interest in developing sustainable materials, frameworks, processes, and environment. The commitment towards sustainability integration could also be demonstrated through resource allocation. Lack of resources could be a key barrier to organizational change towards sustainability integration. These resources could be in the form of human skills and knowledge, natural materials and social structures, machinery, infrastructure and financial assets in the value chain and supply chain arrangements of the firms (UN Global Compact, 2007). As a result, SMEs could overcome the resource constraints they face and also reduce the hindrance on the path of systematically bringing sustainability issues into their operations in alignment with competitive considerations. When management is committed to making their firms sustainable, they will strive to maintain and endeavour to enhance their capital stewardship (Lozano, 2015; Liechti, 2014; Lyneis \& Sterman, 2016). Additionally, SME owners and managers could explore collaborative approaches in a bid to meet sustainability challenges, and also interact with fellow managers of business enterprises to extend sustainability knowledge. Engagement in life-long sustainability learning activities has also proven to be effective towards corporate sustainability integration. Equally imperative, is the facilitation and support for dialogue and debate on sustainability issues to create awareness and increased learning. 


\subsection{Implications for theory}

This study makes significant contributions to theory. The study contributes to the stakeholder theory by advocating the dethronement of the supremacy of shareholders as the focus for profit maximization and the elevation of shared-value creation for all stakeholders. In terms of the social contract theory, the study espouses the view that businesses have an obligation (corporate social responsibility, corporate philanthropy, and corporate governance) towards the communities they operate and society in general. This stance contradicts the instrumental approach that the only obligation of businesses is the maximization of profit for business owners.

\subsection{Implications for practice}

This study has important implications for management and corporate entities. Awareness of corporate sustainability integration into corporate strategic decision-making helps managers to understand why they should aim at creating shared value for all stakeholders instead of shareholders (owners of businesses) alone. It also facilitates understanding of industry players about the implications of their actions or inactions on the planet, people, and their financial performance. The outcome, therefore, augments the paucity of contextually relevant research in the field of study to guide the players since it is still evolving. Furthermore, little of this strand of studies relate to developing nations, especially the sub-Saharan Africa; hence, this study would greatly help fill that gap.

\subsection{Limitations and direction for future studies}

The study has limitations bordering on both theoretical and managerial insights that are useful for further studies and practice. The first limitation relates to the context and the scope of the study. The focus is on corporate sustainability integration into the strategic decision-making of SMEs in Ghana. The business environment and political commitments of the various governments and nations to sustainability issues (SDGs) may not be the same. In light of the above, other studies in countries of similar characteristics like Ghana are needed to further insights into the theory and corporate strategic management practices in developing countries.

\section{Funding}

The author(s) received no financial support for the research, authorship, and/or publication of this article.

\section{Declaration of conflicting interests}

The author(s) declared no potential conflicts of interest with respect to the research, authorship, and/or publication of this article.

\section{Citation information}

Adda, G., Dokor, G. A., Azigwe, J. B., \& Odai. N., A. (2021). Management commitment and corporate sustainability integration into small and medium-scale enterprises: A mediation effect of strategic decision-making. Economics, Management and Sustainability, 6(2), 6-20. doi:10.14254/jems.2021.6-2.1

\section{Reference}

Abid, K. (2013). Integration of corporate sustainability with business processes and its impact on corporate performance. Interdisciplinary Journal of Contemporary Research in Business, 49, 863-885.

Adda, G. (2020). Examining the factors inhibiting corporate sustainability integration into strategic decision- making of small and medium-scale enterprises in Ghana (PhD Theses). CASS European Institute for Management Studies, France.

Asare, A. (2014). Challenges affecting SME's growth in Ghana. OIDA International Journal of Sustainable Development, 7(06), 23-28. 
Ashrafi, M., Acciaro, M., Walker, T. R., Magnan, G. M., \& Adams, M. (2019). Corporate sustainability in Canadian and US maritime ports. Journal of Cleaner Production, 220, 386-397.

Barney, J. B., \& Harrison, J. S. (2020). Stakeholder theory at the crossroads. Business \& Society 59(2), 203-212. https://doi.org/10.1177/0007650318796792

Barry, J., \& Proops, J. (1999). Seeking sustainability discourses with Q methodology. Ecological economics, 28(3), 337-345.

Baumgartner, R. J., \& Ebner, D. (2010). Corporate sustainability strategies: sustainability profiles and maturity levels. Sustainable development, 18(2), 76-89.

Bonn, I., \& Fisher, J. (2011). Sustainability: The missing ingredient in strategy. Journal of Business Strategy, 32(1), 5-14. https://doi.org/10.1108/02756661111100274

Borges, M. L., Anholon, R., Cooper Ordoñez, R. E., Quelhas, O. L. G., Santa-Eulalia, L. A., \& Leal Filho, W. (2018). Corporate Social Responsibility (CSR) practices developed by Brazilian companies: an exploratory study. International Journal of Sustainable Development \& World Ecology, 25(6), 509-517.

Brammer, S., Hoejmose, S., \& Marchant, K. (2012). Environmental management in SME s in the UK: Practices, pressures and perceived benefits. Business Strategy and the Environment, 21(7), 423-434.

Carlson, K. D., \& Herdman, A. O. (2012). Understanding the impact of convergent validity on research results. Organizational Research Methods, 15(1), 17-32.

Carmeli, A., Brammer, S., Gomes, E., \& Tarba, S. Y. (2017). An organizational ethic of care and employee involvement in sustainability-related behaviors: A social identity perspective. Journal of Organizational Behavior, 38(9), 1380-1395.

Christmann, P. (2000). Effects of best practices of environmental management on cost advantage: The role of complementary assets. Academy of Management Journal, 43, 663-680.

Cici, C., \& D'Isanto, D. (2017). Integrating sustainability into core business. Symphonya. Emerging Issues in Management, (1), 50-65. https: //doi.org/10.4468/2017.1.05cici.disanto

Cohen, B., \& Winn, M. I. (2007). Market imperfections, opportunity and sustainable entrepreneurship. Journal of business venturing, 22(1), 29-49.

Creswell, J. W., \& Creswell, J. D. (2017). Research design: Qualitative, quantitative, and mixed methods approaches. Sage publications.

Cronbach, L.J. (1951). Coefficient alpha and the internal structure of tests. Psychometrika, 16(3), 297334.

Dassah, M. O. (2010). Responsible Leaders: Attributes and Roles in a Multi-challenged Global Business Environment and Implications for Leadership Development. The Next Generation Responsible Leaders, 30-37.

Dunphy, D., Griffiths, A., Benn, S. (2006). Organizational change for corporate sustainability: A guide for leaders and change agents of the future, 2nd ed, Routledge, New York City.

Dyllick, T., \& Hockerts, K. (2002). Beyond the business case for corporate sustainability. Business strategy and the environment, 11(2), 130-141.

Dyllick, T., \& Muff, K. (2015). Clarifying the meaning of business; from business as usual to true sustainability. Journal for Organisation and Environment, 1- 19.

Eccles, R. G., Ioannou, I., \& Serafeim, G. (2014). The impact of corporate sustainability on organizational processes and performance.Management Science,60(11), 2835-2857. https://doi.org/10.1287/mnsc.2014.1984

Ehnert, I., \& Ehnert, I. (2009). Sustainable human resource management. Physica-Verlag.

Euler, D., \& Hahn, A. (2007). Wirtschaftsdidaktit. 2nd edition. Bern: Haupt.

Farla, J. C. M., Markard, J., Raven, R., \& Coenen, L. E. (2012). Sustainability transitions in the making: A closer look at actors, strategies and resources. Technological forecasting and social change, 79(6), 991-998. https://doi.org/10.1016/j.techfore.2012.02.001

Field, A. (2009). Discovering Statistics Using SPSS. Sage Publications Ltd., London. 
Figge, F., Hahn, T., Schaltegger, S., \& Wagner, M. (2002). The sustainability balanced scorecardlinking sustainability management to business strategy. Business strategy and the Environment, 11(5), 269-284. https://doi.org/10.1002/bse.339

Galpin, T.J., \& Hebard, J., (2018). Strategic Management and Sustainability, in Borland, Lindgreen, Vanhamme, Maon, Ambrosini, and Palacios Florencio (Ed.), Business Strategies for Sustainability: A Research Anthology. (pp. 165-178). New York, NY: Routhledge

George, R. A., Siti-Nabiha, A. K., Jalaludin, D., \& Abdalla, Y. A. (2016). Barriers to and enablers of sustainability integration in the performance management systems of an oil and gas company. Journal of Cleaner Production, 136, 197-212.

Golini, R., Longoni, A., \& Cagliano, R. (2014). Developing sustainability in global manufacturing networks: The role of site competence on sustainability performance. International Journal of Production Economics, 147, 448-459.

Hair Jr, J. F., Hult, G. T. M., Ringle, C. M., \& Sarstedt, M. (2021). A primer on partial least squares structural equation modeling (PLS-SEM). Sage publications.

Halstenberg, F. A., Steingrímsson, J. G., \& Stark, R. (2017). Material reutilization cycles across industries and production lines. In Sustainable Manufacturing (pp. 163-173). Springer, Cham. https://doi.org/10.1007/978-3-319-48514-0_1

Harmon, J., Fairfield, K. D., \& Behson, S. (2009, June). A comparative analysis of organizational sustainability strategy: Antecedents and performance outcomes perceived by US and Non-US based managers. In Proceedings of the International Eastern Academy of Management Conference, Rio de Janeiro, Brazil (pp. 21-25).

Henseler, J., Ringle, C. M., \& Sarstedt, M. (2015). A new criterion for assessing discriminant validity in variance-based structural equation modeling.Journal of the academy of marketing science, 43(1), 115-135.

Hörisch, J., Freeman, R. E., \& Schaltegger, S. (2014). Applying stakeholder theory in sustainability management: Links, similarities, dissimilarities, and a conceptual framework. Organization \& Environment, 27(4), 328-346. https://doi.org/10.1177/1086026614535786

Horová, M. (2012, November). Performance Audit Considering the Sustainability: Approach of the Czech Enterprises. In Proceedings of the 8th European Conference on Management, Leadership and Governance, Academic Publishing International Limited, Reading (pp. 231-236).

Jin, Z., \& Bai, Y. (2011). Sustainable development and long-term strategic management: Embedding a long-term strategic management system into medium and long-term planning. World Future Review, 3(2), 49-69.

Kaldschmidt, S. (2011). The values of sustainability: The influence of leaders' personal values on sustainability strategies. na.

Kock, N. (2017). Structural equation modeling with factors and composites: A comparison of four methods. International Journal of e-Collaboration (IJeC), 13(1), 1-9.

Kock, N. (2017). WarpPLS user manual: Version 6.0. ScriptWarp Systems: Laredo, TX, USA, 141.

Kolk, A., \& Van Tulder, R. (2010). International business, corporate social responsibility and sustainable development. International business review, 19(2), 119-125.

Leisinger, K. M. (2007). Capitalism with a human face: The UN Global Compact. Journal of Corporate Citizenship, (28), 113-132.

Liechti, A. (2014). Collaboratories als wirksame Methode zur Ausbildung von verantwortungsvollen Führungskräften?: eine Untersuchung des Kompetenzgewinns von Studierenden im Rahmen des Kurses" Strategien für eine nachhaltige Entwicklung" an der Universität St. Gallen (Doctoral dissertation).

Lindgreen, A., Swaen, V., \& Maon, F. (2009). Introduction: Corporate social responsibility implementation. Journal of Business Ethics, 85(2), 251-256.

Lozano, R. (2015). A holistic perspective on corporate sustainability drivers. Corporate social responsibility and environmental management, 22(1), 32-44. https://doi.org/10.1002/csr.1325 
Lyneis, J., \& Sterman, J. (2016). How to save a leaky ship: Capability traps and the failure of win-win investments in sustainability and social responsibility. Academy of Management Discoveries, 2(1), 7-32.

Mansfield, E.R., \& Helms, B.P. (1982). Detecting multicollinearity. The American Statistician, 36(3a), 158-160.

Michelon, G., Boesso, G., \& Kumar, K. (2013). Examining the link between strategic corporate social responsibility and company performance: An analysis of the best corporate citizens. Corporate social responsibility and environmental management, 20(2), 81-94.

Mintzberg, H. (1987). Crafting Strategy. The Mckinsey Quaterly.

Mintzberg, H. (1990). Strategy Formation: Schools of Thought. In: Frederickson, J., Ed., Perspectives on Strategic Management, Harper Business, New York, 105-237.

Peprah, J. A., Mensah, A. 0., \& Akosah, N. B. (2016). Small and medium sized enterprises (SMEs) accessibility to public procurement: SMEs entity perspective in Ghana. European Journal of Business and Social Sciences, 4(11), 25-40.

Pirson, M. A., \& Lawrence, P. R. (2010). Humanism in business-towards a paradigm shift?. Journal of Business Ethics, 93(4), 553-565. https://doi.org/10.1007/s10551-009-0239-1

Pless, N.M., Maak, T., \& Stahl, G.K. (2012). Promoting corporate social responsibility and sustainable development through management development: what can be learned from international service learning programs?. Hum. Resour. Manag., 51(6), 873- 904.

Porter, M. E., \& Kramer, M. R. (2006). Strategy and society: the link between corporate social responsibility and competitive advantage. Harvard business review, 84(12), 78-92.

Porter, M., \& Kramer, M. (2011). Creating shared value: How to reinvent capitalism and unleash a way of innovation and growth. Harvard Bus. Rev., 89(1/2), 62-77.

Revell, A., Stokes, D., \& Chen, H. (2010). Small businesses and the environment: turning over a new leaf?. Business strategy and the environment, 19(5), 273-288.

Roome, N. (1992). Developing environmental management strategies. Business strategy and the environment, 1(1), 11-24. https://doi.org/10.1002/bse.3280010104

Röring, M., Herr, R., Fiala, G. J., Heilmann, K., Braun, S., Eisenhardt, A. E., ... \& Brummer, T. (2012). Distinct requirement for an intact dimer interface in wild-type, V600E and kinase-dead B-Raf signalling. The EMBO journal, 31(11), 2629-2647.

Russo, A., \& Tencati, A. (2009). Formal vs. informal CSR strategies: Evidence from Italian micro, small, medium-sized, and large firms. Journal of Business Ethics, 85(2), 339-353.

Salzmann, O., Ionescu-Somers, A., \& Steger, U. (2005). The business case for corporate sustainability: Literature review and research options. European Management Journal, 23(1), 27-36.

Schaltegger, S., \& Wagner, M. (2006). Managing the business case of sustainability, Sheffield: Greenleaf.

Schaltegger, S., \& Wagner, M. (2011). Sustainable entrepreneurship and sustainability innovation: categories and interactions. Business strategy and the environment, 20(4), 222-237.

Schwab, K. (2019, December). Davos Manifesto 2020: The universal purpose of a company in the fourth industrial revolution. In World economic forum (Vol. 2).

Searcy, C. (2016). Measuring enterprise sustainability. Business Strategy and the Environment, 25(2), 120-133.

Sekaran, U., \& Bougie, R. (2010). Research methods for business: A skill building approach 5th ed. West Sussex: John Wiley \& Sons.

Shevlin, M., \& Miles, J. N. (1998). Effects of sample size, model specification and factor loadings on the GFI in confirmatory factor analysis. Personality and Individual differences, 25(1), 85-90.

Shibia, A. G., \& Barako, D. G. (2017). Determinants of micro and small enterprises growth in Kenya.Journal of Small Business and Enterprise Development, 24, 105-118. https://doi.org/10.1108/JSBED-07-2016-0118 
Smith, N. C., \& Rönnegard, D. (2016). Shareholder primacy, corporate social responsibility, and the role of business schools. Journal of Business Ethics, 134(3), 463-478. https://doi.org/10.1007/s10551-014-2427

Sroka, W., \& Szántó, R. (2018). Corporate social responsibility and business ethics in controversial sectors: Analysis of research results. Journal of Entrepreneurship, Management and Innovation, 14(3), 111-126.

Sterling, S., \& Thomas, I. (2006). Education for sustainability: the role of capabilities in guiding university curricula. International Journal of Innovation and Sustainable Development, 1(4), 349-370.

Svanström, M., Lozano-García, F. J., \& Rowe, D. (2008). Learning outcomes for sustainable development in higher education. International Journal of Sustainability in Higher Education, 9(3), 339-351.

Sweeney, L., (2009). A study of current practice of corporate social responsibility (CSR) and an examination of the relationship between CSR and financial performance using structural equation modelling (SEM) (PhD thesis). Dublin Institute of Technology, Dublin.

Székely, F., \& Knirsch, M. (2005). Responsible leadership and corporate social responsibility: Metrics for sustainable performance. European Management Journal, 23(6), 628-647. https://doi.org/ 10.1016/j.emj.2005.10.009

Van Marrewijk, M. (2003). Concepts and definitions of CSR and corporate sustainability: Between agency and communion. Journal of business ethics, 44(2), 95-105.

Vandaele, N. J., \& Decouttere, C. J. (2013). Sustainable R\&D portfolio assessment. Decision Support Systems, 54(4), 1521-1532. https://doi.org/10.1016/j.dss.2012.05.054

Wiek, A., Withycombe, L., \& Redman, C. L. (2011). Key competencies in sustainability: a reference framework for academic program development. Sustainability science, 6(2), 203-218.

Yeboah, M. A. (2021). Determinants of SME growth: An empirical perspective of SMEs in the Cape Coast Metropolis, Ghana. The journal of business in developing nations, 14, 1-31.

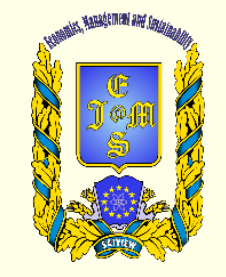

(C) 2016-2020, Economics, Management and Sustainability. All rights reserved.

This open access article is distributed under a Creative Commons Attribution (CC-BY) 4.0 license.

You are free to:

Share - copy and redistribute the material in any medium or format Adapt - remix, transform, and build upon the material for any purpose, even commercially.

The licensor cannot revoke these freedoms as long as you follow the license terms.

Under the following terms:

Attribution - You must give appropriate credit, provide a link to the license, and indicate if changes were made.

You may do so in any reasonable manner, but not in any way that suggests the licensor endorses you or your use.

No additional restrictions

You may not apply legal terms or technological measures that legally restrict others from doing anything the license permits.

Economics, Management and Sustainability (ISSN: 2520-6303) is published by Scientific Publishing House "CSR", Poland, EU and Scientific Publishing House "SciView", Poland

Publishing with JEMS ensures:

- Immediate, universal access to your article on publication

- High visibility and discoverability via the JEMS website

- Rapid publication

- Guaranteed legacy preservation of your article

- Discounts and waivers for authors in developing regions

Submit your manuscript to a JEMS at http://jems.sciview.net or submit.jems@sciview.net

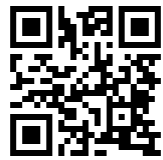

